\title{
Interaction between anticoagulants and contraceptives: an unsuspected finding
}

\author{
E DE TERESA, A VERA, J ORTIGOSA, L ALONSO PULPON, A PUENTE ARUS, M DE ARTAZA
}

British Medical fournal, 1979, 2, 1260-1261

\section{Summary and conclusions}

To assess the effects of oral contraceptives on anticoagulant treatment the prothrombin times of 12 patients were measured while they were taking both drugs simultaneously and while they were taking only anticoagulants. The mean prothrombin time ratio was significantly higher when patients were taking both drugs than when they were taking only anticoagulants and their doses of anticoagulant were significantly lower. During both periods most of the prothrombin values remained in the therapeutic range.

These findings suggest that, contrary to the common belief that oral contraceptives diminish the effects of anticoagulants, contraceptives in fact potentiate the action of the anticoagulants.

\section{Patients and methods}

Among the 197 patients being followed in our anticoagulation control unit we found 12 women who were simultaneously taking an oral anticoagulant (nicoumalone) and an oestroprogestogenic oral contraceptive. In one case the contraceptive was a parenteral depot preparation, while the remaining 11 patients used oral preparations (see table). The patients were aged 27 to 44 years (mean 34.5), and none suffered from nephropathy, hepatopathy, or hypertensive disease.

The indication for anticoagulation was the presence of a BjörkShiley valvular prosthesis in nine patients (five mitral, one aortic, three mitral and aortic), and the existence of embolic mitral valve disease in three patients.

Anticoagulation control was carried out by measuring prothrombin activity according to Quick's method. Commercially obtained thromboplastin was used, but the reference values were from British comparative thromboplastin (BCT), and adequate correlations were established. ${ }^{2}$ The therapeutic range for commercial thromboplastin ranged generally from 1.3 to 1.8 , corresponding to a prothrombin time ratio of 2 to 3 with BCT.

The patients were followed for a total of 374 patient-months (mean

Dose of oral anticoagulant and prothrombin time ratio while patients were also taking oral contraceptives

\begin{tabular}{|c|c|c|c|c|c|c|c|}
\hline \multirow{2}{*}{$\begin{array}{l}\text { Case } \\
\text { No }\end{array}$} & \multirow{2}{*}{$\begin{array}{c}\text { Oral } \\
\text { contraceptive }\end{array}$} & \multicolumn{3}{|c|}{ Phase A } & \multicolumn{3}{|c|}{ Phase B } \\
\hline & & $\begin{array}{l}\text { No of } \\
\text { months }\end{array}$ & Dose & $\begin{array}{c}\text { Prothrombin } \\
\text { time ratio }\end{array}$ & $\begin{array}{l}\text { No of } \\
\text { months }\end{array}$ & Dose & $\begin{array}{c}\text { Prothrombin } \\
\text { time ratio }\end{array}$ \\
\hline 1 & Neogynona & 25 & 2.21 & 1.62 & 9 & 2.19 & 1.66 \\
\hline $\begin{array}{l}2 \\
3 \\
4\end{array}$ & Microgynon & $\begin{array}{l}28 \\
28\end{array}$ & $\begin{array}{l}2.02 \\
1.21\end{array}$ & $\begin{array}{l}1.68 \\
1.70\end{array}$ & 5 & & \\
\hline $\begin{array}{l}4 \\
5\end{array}$ & $\begin{array}{l}\text { Neogynona } \\
\text { Fugrion }\end{array}$ & 13 & $\begin{array}{l}1.75 \\
2.24\end{array}$ & $\begin{array}{l}1.89 \\
1.74\end{array}$ & 11 & $\begin{array}{l}1.79 \\
3.08\end{array}$ & $\begin{array}{l}1.46 \\
1.47\end{array}$ \\
\hline 6 & $\begin{array}{l}\text { Eugynon } \\
\text { Neogynona }\end{array}$ & $\begin{array}{r}14 \\
3\end{array}$ & 2.00 & $\begin{array}{l}1.14 \\
1.72\end{array}$ & 32 & 2.40 & $\begin{array}{l}1.47 \\
1.52\end{array}$ \\
\hline 7 & Topasel & 27 & $\begin{array}{l}1.97 \\
1.97\end{array}$ & $\begin{array}{l}1.67 \\
1.67\end{array}$ & 4 & 2.00 & 1.50 \\
\hline 8 & Eugynon & 25 & 2.84 & 1.52 & 8 & 2.87 & $\begin{array}{l}1.47 \\
1.54\end{array}$ \\
\hline $\begin{array}{r}9 \\
10\end{array}$ & $\begin{array}{l}\text { Neogynona } \\
\text { Fuynon }\end{array}$ & 13 & $\begin{array}{l}3.02 \\
1.63\end{array}$ & 1.63 & 21 & $\begin{array}{l}3.47 \\
1.75\end{array}$ & 1.54 \\
\hline 11 & $\begin{array}{l}\text { Eugynon } \\
\text { Neogynona }\end{array}$ & 12 & $\begin{array}{l}1.63 \\
2.05\end{array}$ & $\begin{array}{l}1.72 \\
1.77\end{array}$ & 20 & 2.29 & $\begin{array}{l}1.62 \\
1.41\end{array}$ \\
\hline 12 & , & 29 & 2.00 & 1.65 & 4 & $2 \cdot 10$ & 1.42 \\
\hline & 8 & 230 & 7 & $1.67: 0.08$ & 144 & $3: 0.54$ & $0=0$ \\
\hline
\end{tabular}

Neogynona: $0.05 \mathrm{mg}$ ethinyloestradiol and $0.25 \mathrm{mg}$ D-norgestrel. Microgynon: 0.03 ethinyloestradiol and $0.15 \mathrm{mg}$ D-norgestrel. Eugynon: $0.05 \mathrm{mg}$ ethinyloestradiol and $0.5 \mathrm{mg}$ D-norgestrel. Topasel: intramuscular ampoules $10 \mathrm{mg}$ vestradiol enanthate and $150 \mathrm{mg}$ dihydroxyprogesterone acetophenide.

\section{Introduction}

Pregnancy is not advisable for women with heart disease taking anticoagulants because of the high risk to both mother and fetus. Because of their effect on the processes of coagulation, ${ }^{1}$ oral contraceptives may modify the action of oral anticoagulants. We reviewed a group of women with heart disease who were taking both oral contraceptives and anticoagulants to ascertain whether any interaction occurred and, if so, what effects it had.

Division of Cardiology, Clinica Puerta de Hierro, Madrid, España E DE TERESA, MD, associate physician

A VERA, MD, resident physician

J ORTIGOSA, MD, resident physician

L ALONSO PULPON, MD, associate physician

A PUENTE ARUS, $M D$, resident physician

$M$ DE ARTAZA, MD, head of division
31.2 months (patient). During 230 months the patients were taking anticoagulants and oral contraceptives simultaneously (phase A), and in the remaining 144 months they took only anticoagulants (phase B). In each phase the mean prothrombin time ratio for each patient was recorded, as well as the mean dose of anticoagulant required.

\section{Results}

The results are shown in the table-the mean prothrombin time ratio in phase $\mathrm{A}(1.67 \pm 0.08)$ was significantly higher than in phase $\mathrm{B}$ $(1.50 \pm 0.06 ; \mathrm{P}<0.01)$. These findings coincided with a lesser mean requirement for anticoagulant medication in phase $A(2.05 \pm 0.47 \mathrm{mg}$ nicoumalone) than in phase $\mathrm{B}(2.53 \pm 0.54 \mathrm{mg} ; \mathrm{P}<0.01)$. In the periods of oral contraceptive use therefore our patients were anticoagulated to a higher degree despite their lower doses of anticoagulant, which indicates a potentiation of the effects of the anticoagulant by the oral contraceptive.

Out of a total of 399 measurements of prothrombin time made in these patients, $350\left(88^{\prime \prime}{ }^{\prime \prime}\right)$ yielded values within the therapeutic range; 247 of these measurements were made in phase $A$ and 152 in phase B, and the proportions of the values that were in the therapeutic range were $90.0^{\circ}{ }_{0}$ and $82 \cdot 8^{\circ}$, respectively. 


\section{Discussion}

Our findings indicate, firstly, that a therapeutic degree of anticoagulation can be maintained even though hormonal contraceptives are being administered simultaneously, and, secondly, that oral contraceptives seem to potentiate the action of oral anticoagulants, although this effect is not clinically significant, and slight adjustments in the anticoagulant dose are enough to maintain prothrombin activity within the therapeutic range.

Our second conclusion does not agree with the generally accepted belief that oral contraceptives would diminish the effects of oral anticoagulants. ${ }^{3}$ This has been thought to occur through procoagulant action at three levels: (a) increased concentrations of certain coagulation factors, mainly factor VII and factor $\mathrm{X}^{45} ;(b)$ diminished concentrations of antithrombin III $^{6}$; and $(c)$ a local effect on vascular endothelia. ${ }^{7}$ Nevertheless, interaction between oral anticoagulants and oral contraceptives is quite possible at other levels, some of them imperfectly understood. The synthetic oestrogens contained in oral contraceptives may produce enzymatic inhibition in the microsomes of the hepatic cells ${ }^{8}$ which would potentiate the action of anti- coagulants through retarded metabolic degradation. ${ }^{10}$ The resultant interaction may represent only the net balance of opposing actions, which will require further study and clarification.

\section{References}

${ }^{1}$ Kaplan, N M, Annual Review of Medicine, 1978, 29, 31.

2 Poller, L, Thrombosis et Diathesis Haemorrhagica, 1975, 33, 157.

${ }^{3}$ American Pharmaceutical Association, Evaluation of Drug Interactions. Washington, APA, 1976.

${ }^{4}$ Scherogie, J J, Solomon, H M, and Zieve, P D, Clinical Pharmacology and Therapeutics, 1967, 8, 670 .

${ }^{5}$ Poller, L, et al, British Medical fournal, 1969, 1, 554.

6 Bounaemeaux, H, et al, Thrombosis et Diathesis Haemorrhagica, 1978, 39, 607.

${ }^{7}$ Srinivasan, S, et al, Contraception, 1974, 9, 291.

${ }^{8}$ Klatskin, G, Diseases of the Liver. Philadelphia, Lippincott, 1975.

9 Song, C S, and Kappas, A, Diseases of the Liver. Philadelphia, Lippincott, 1975.

${ }^{10}$ Koch-Weser, J, and Sellers, E M, New England fournal of Medicine, $1971,285,547$.

(Accepted 29 August 1979)

\section{SHORT REPORTS}

\section{Survival after bilateral renal artery occlusion}

Embolic occlusion of a renal artery is uncommon and the clinical diagnosis made rarely. We report a case of sequential bilateral renal emboli successfully treated conservatively without surgical intervention.

\section{Case report}

A 64-year-old man with a history of hypertension and ischaemic heart disease was admitted with a two-day history of right-sided abdominal pain and vomiting. He had atrial fibrillation, a blood pressure of $160 / 80 \mathrm{~mm} \mathrm{Hg}$, and tenderness in the right loin. An intravenous urogram (IVU) showed a non-functioning right kidney. Several hours after admission he complained of a cold, rumb right arm with absent arterial pulsation distal to the axillary artery. Right brachial embolectomy was performed under local anaesthesia. After this a renal arteriogram showed emboli in the right artery (figure). The left renal arterial tree was normal. Anticoagulant treatment with heparin was given and continued after discharge by subcutaneous self-administration (7500 units eight hourly). An oral anticoagulant was not used because of a history of heavy alcohol consumption and abnormal liver-function test results. One month later the patient was readmitted with anuria and complaining of severe left-sided abdominal pain. An IVU showed no function in either kidney. A renal arteriogram showed a patent right renal artery, though some branches were occluded, and much reduced perfusion of the left kidney, suggesting gross infarction. Streptokinase $100000 \mathrm{U}$ was injected into the left renal artery. Forty-eight hours later he was still anuric with severe hyperkalaemia and a metabolic acidosis. Serum creatinine concentration was $1110 \mu \mathrm{mol} / 1(12.5 \mathrm{mg} / 100 \mathrm{ml})$. Peritoneal dialysis was started together with intravenous heparin 10000 units six hourly. Seven days later he began to pass urine, and by day 14 his renal function was sufficient to discontinue dialysis (serum creatinine concentration $170 \mu \mathrm{mol} / 1(1.9 \mathrm{mg} /$ $100 \mathrm{ml})$ ). He was discharged home on warfarin. A subsequent IVU showed recovery of function in both kidneys.

\section{Comment}

The diagnosis of renal artery embolism is often delayed because its clinical features are common to other conditions. In this case the right brachial artery embolus led to early diagnosis of the first episode. Previously reported cases have shown that kidney function may return despite prolonged interruption of blood flow. Some protection may be given by the small collateral venovenous anastomoses from the ureter, the capsule, and the perinephric tissues. ${ }^{1}$ The renal artery pressure may be inadequate for filtration but at $25 \mathrm{~mm} \mathrm{Hg}$ will still maintain renal integrity. ${ }^{2}$ Other possible explanations for recovery of renal function include spontaneous fibrinolysis, recanalisation of the artery, or intense vasospasm associated with occlusion of a segmental branch of the renal artery with vasoconstriction producing a syndrome similar to acute tubular necrosis. ${ }^{3}$ The duration of the renal failure in our patient favours the latter explanation, and segmental occlusion of a renal artery is known to cause complete non-visualisation on an IVU. ${ }^{4}$

We believe that this is the first reported case of bilateral sequential renal emboli with survival after medical treatment alone. Moyer et al $l^{5}$ reviewed confirmed reports of renal artery embolism over the past 20 years and found 39 cases, of which 24 were treated surgically with six deaths and 15 were treated medically with two deaths. Renal function recovered in 10 of the survivors treated medically and in seven treated surgically. The success of medical treatment in this condition questions
Renal arteriogram showing embolisation of right renal arterial tree. Normal left renal arterial circulation. 